\title{
Animated Pathway Interactive Map
}

\author{
Arie Budiansyah ${ }^{1}$ \\ Informatika, MIPA, Universitas Syiahkuala \\ arie.b@unsyiah.ac.id \\ Taufiq Abdul Gani ${ }^{3}$ \\ Teknik Elektro dan Komputer, Teknik, \\ Universitas Syiahkuala \\ topgan@unsyiah.ac.id
}

\author{
Rudi Arif Candra ${ }^{2}$ \\ Teknik Komputer, Politeknik Aceh Selatan \\ Tapaktuan, Aceh-Indonesia \\ rudi_candra@poltas.ac.id \\ Dirja Nur Ilham ${ }^{4}$ \\ Teknik Komputer, Politeknik Aceh Selatan \\ Tapaktuan, Aceh-Indonesia \\ dirja@poltas.ac.id
}

\author{
Siti Rusdiana ${ }^{5}$ \\ Matematika, MIPA, Universitas Syiahkuala \\ siti.rusdiana@unsyiah.ac.id
}

\begin{abstract}
A map is one of the cartographic scientific products that is used as a guide to access locations or places. The use of information technology and computer systems in cartography can increase the value of map products to be interactive and can be accessed online via the internet. This interactive map of the Unsyiah Director Office building is the development of an interactive map product of the author with the addition of an animated pathway from the reference point to the location point. With these additions, it will be easier for visitors to access the location
\end{abstract}

Keywords - Interactive Map, flash, action script, animated pathway

\section{INTRODUCTION}

Maps are cartographic scientific products that are used to guide locations or places (Rahman, 2019). Along with the development of information technology and electronic devices, the form of maps is no longer made from paper, wood, iron but has transformed into a set of digital electronics by utilizing computer systems such as wide touchscreen monitors, computer machines and connected to the internet network that allows the change of map content easily and quickly without the need to come to the location of the map. Maps also become interactive via the touch screen and store more contents.

This research is an interactive map product that utilizes the latest information technology and computer systems. The case taken in this study was the office building of the Director of Syiah Kuala University. Case selection is based on the area and number of floors of a building that often confuses visitors to go to a room for academic purposes or meet someone. With the interactive building map, it will certainly help the building customer services officer in directing visitors to the intended location.
There has been a lot of research related to interactive maps such as interactive web-based maps, mobile gis maps, interactive maps of Unsyiah library buildings and so on. This research is the development of the author's previous research on interactive maps. The difference is that there is already an additional feature in the form of routing animation from the place of origin to the destination on the map of the Kuala University bureau building. This interactive map uses a Macromedia flash software tool that is widely used on the campus where the author works. The advantage of using this software is that the resulting map products can be offline maps or centralized online maps. The offline nature of the map is very useful when the internet connection is lost and the map still works (Marshadri, 2018). In contrast to centralized online maps will also be interrupted because map images cannot be sent to the map location. Interactive map products made with Macromedia Flash software are very small compared to web programming based maps, especially since there is already GIS technology that will make large map files and query processes slow. However, there is a lack of this Macromedia flash map that is no longer supported in browsers such as Chrome, 
Internet Explorer, Firefox, Safari but the Penguin browser.

Because of the factors above, the authors chose to develop further interactive maps made from Macromedia flash. Meanwhile, the author has made 4 Macromedia flash interactive maps namely Unsyiah library building map (Firdaus, 2016), Unsyiah campus map (Bahri, 2016), Sabang Island tourism map (Marshadri, 2018), store location map at Pasar Aceh Center building (Munandar, 2017). The difference in the Unsyiah bureau building map is the addition of the animation path feature to the location to be addressed.

\section{RESEARCH METHOD}

This map development method uses an experimental method for refinement and improvement of interactive map components. In the process of making this interactive map there are 5 steps of making the design of the image, making images, injection of images, injection of animated lines and the fifth determination of distance based on the location of the road in the building.

\subsection{Materials and Equipments}

Tools and materials used in making this interactive map include hardware and software. For hardware such as laptops, cameras, stationery, and measuring devices. For software such as Macromedia Flash, Adobe Photoshop, Sweet Home 3D, Notepad ++ and Google Earth.

Table 1. Materials and Supporting Devices.

\begin{tabular}{ll}
\hline \multicolumn{1}{c}{ Product } & \multicolumn{1}{c}{ Server } \\
\hline Laptop & Asus \\
Kamera & HP Oppo \\
Stationery & Kertas, pinsil, pulpen \\
Measuring & Meteran \\
Device & \\
Flash & Macromedia Flash \\
OS & Windows 8.0 \\
Design & Sweet Home 3D \\
Program & Notepad++ \\
Scale & Google Earth \\
\hline
\end{tabular}

\subsection{Sketch Design Planning}

At this stage, the original image data taken such as names and photos of the room, room plans, markings of front door objects, rear side and stairs.
Then the size of the image scale is gained from Google Earth. All the points are sketched first on paper using stationery after that it is checked to make sure the sketch of the drawing resembles the original one.

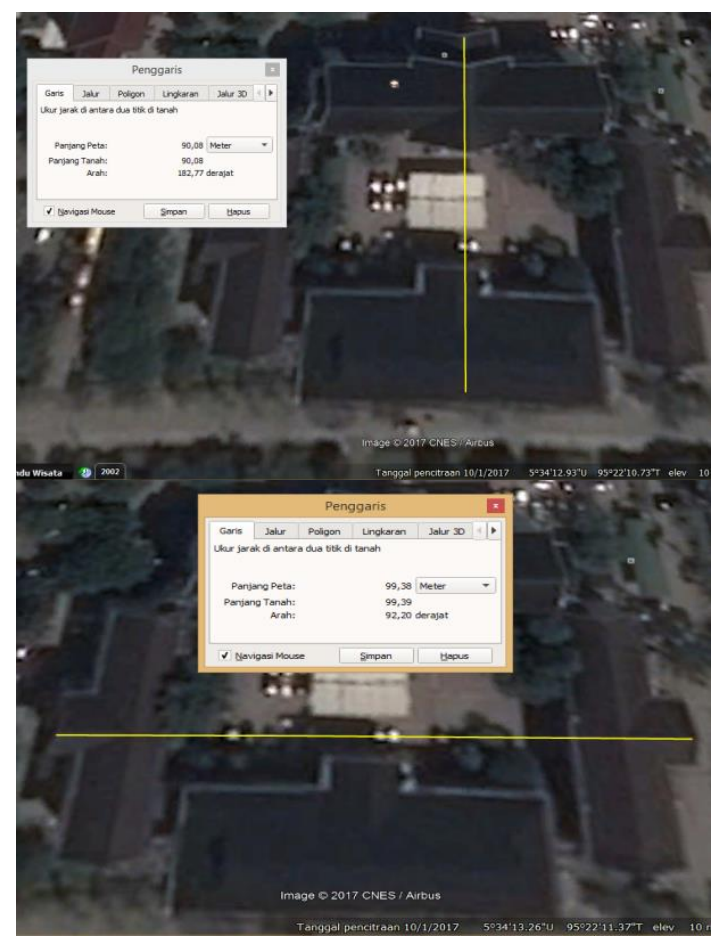

Figure 1. Measuring the scale of images of the Unsyiah Director's Office Building via Google Earth.

\subsection{Map Image Development}

At this stage, what is done is to transfer the sketch image to the 3D home sweet digital media as shown. In this process, location menus are also added based on floor 1 , floor 2 , and floor 3 . On each floor, a dropdown menu will appear showing the names of the rooms. The image size is made as wide as the monitor screen with full-screen mode. 


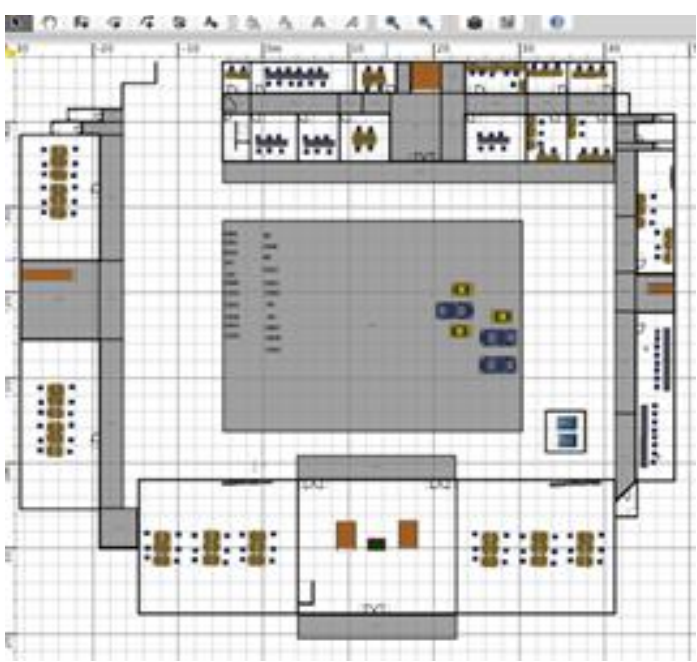

Figure 2. Drawing sketches on Sweet Home 3D software.

\subsection{Image injection}

At this stage, the injection of an action image is performed, when an image plan is touched it will bring up a pop-up of the room's photo. The emergence of this photo pop-up is the location to be addressed so that visitors know the original photo. Besides, the flow menu of information transfer of images per level is made to make room plans visible per level.

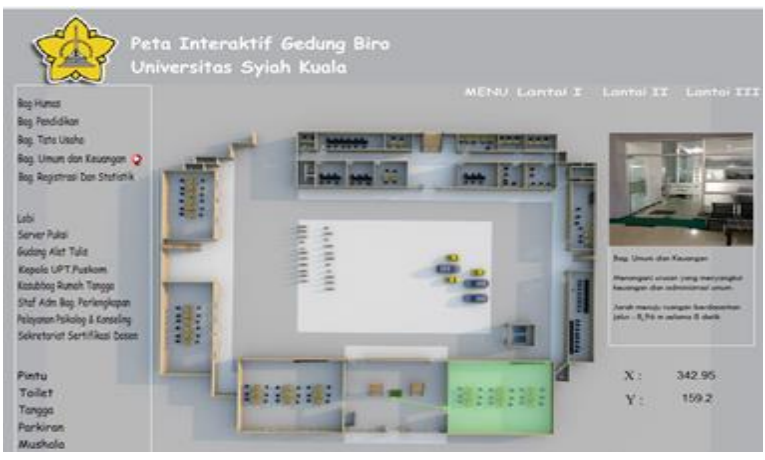

Figure 3. Injection action script on the points of the image and menu will bring up the photo on the right hand side.

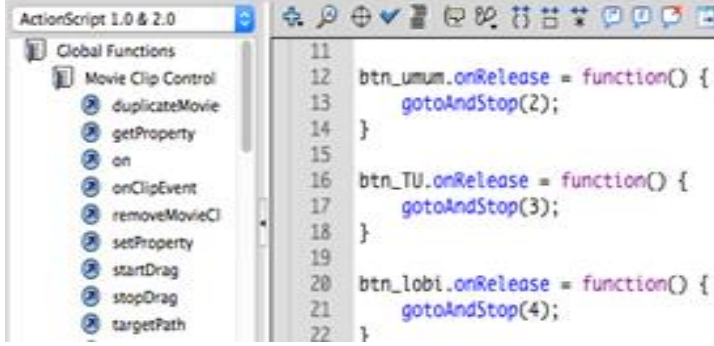

Figure 4. Action script injection program in the map image

\subsection{Animated Path Injection}

At this final stage, an animated line path is created from the location of the visitor to the location of the intended space. The animation is in the form of a line moving along the path inside the Unsyiah Director's Office building.

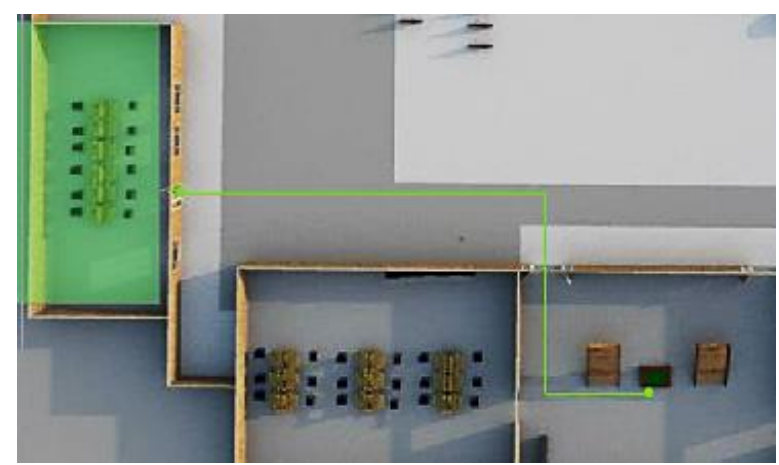

Figure 5. Injection action script in the image that raises the path from the reference point to the destined location.

\subsection{Determination of Distance Based on Paths Inside the Building.}

To determine the distance of a location from a reference point to location uses the formulas (1) and (3). Where $d$ is the distance you want to know and $x$ is the horizontal coordinate point and $y$ is the vertical coordinate point. The horizontal distance is determined by the coordinates $\left(x_{n+1}-x_{n}\right)^{2}$ while the vertical distance is determined by $\left(y_{n+1}-y_{n}\right)^{2}$.

$$
\begin{aligned}
& d_{\text {total }}=\sum_{i=1}^{n} d_{i} \\
& d_{n}=\sqrt{\left(x_{n+1}-x_{n}\right)^{2}+\left(y_{n+1}-y_{n}\right)^{2}}
\end{aligned}
$$




\section{RESULT AND DISCUSSION}

The interactive map of the Unsyiah Director's Office building has an interactive function for its users by touching parts of the photo pop-up or the actual appearance. The appearance of the map from the top gives a comprehensive view of the floor plan per level, making it easier to explain the map image. If the visitor only knows the name of the room but does not know the location where the visitor can search for the name of the room and touch it on the left menu then an icon will appear in the picture that shows the location of the location.

This interactive map has an additional feature in the form of an animated path that can show the path from the reference point or the initial location to the location of the intended room with an estimated distance in meters.

This interactive map is run on a browser application so that it can work in both offline and online mode with public IP or integrated within a web server. The size of the map file is $2 \mathrm{MB}$, relatively light to accommodate map images in 3-dimensional shapes, room photos, action script programs, and path animation programs. With this small file size, the process of working maps becomes faster.

\section{CONCLUSION}

Interactive maps created with action scripts in Macromedia flash or Adobe flash software are very interesting, interactive, easy and inexpensive. Easy means that the maker of human resources is in the Unsyiah campus environment because it is taught in the Mathematics study program, Diploma in Information Management, Informatics, Electrical Engineering and Computer Engineering. Inexpensive means to run this map using specifications such as the linux operating system, penguin browser, 1GB RAM and $1 \mathrm{Mbps}$ internet connection.

\section{ACKNOWLEDGEMENT}

Thank you to Ms. Siti Rusdiana, Ms. Lidar Head of Mathematics Study Program. Mr. Mahyus for the cooperation and constructive criticism for the perfection of this interactive map.

\section{REFERENCES}

Bahri, S. (2016). IMPLEMENTASI XML FLASH DALAM PEMBUATAN PETA INTERAKTIF UNSYIAH. In F. Firdaus, IMPLEMENTASI XML FLASH DALAM PEMBUATAN PETA INTERAKTIF UNSYIAH. Banda Aceh: Universitas Syiahkuala.

Firdaus, F. (2016). IMPLEMENTASI XML FLASH DALAM PEMBUATAN DENAH RUANGAN INTERAKTIF GEDUNG PERPUSTAKAAN UNSYIAH. In F. Firdaus, IMPLEMENTASI XML FLASH DALAM PEMBUATAN DENAH RUANGAN INTERAKTIF GEDUNG PERPUSTAKAAN UNSYIAH. Banda Aceh: Universitas Syiahkuala.

Marshadri, M. (2018). ANALISA KEPUASAN PEMETAAN INTERAKTIF LOKASI PARIWISATA DAN FASILITAS UMUM PULAU SABANG. In M. Marshadri, ANALISA KEPUASAN PEMETAAN INTERAKTIF LOKASI PARIWISATA DAN FASILITAS UMUM PULAU SABANG. Banda Aceh: Universitas Syiahkuala.

Munandar, M. (2017). PEMETAAN INTERAKTIF LETAK TOKO LANTAI 1 DI PASAR ATJEH MENGGUNAKAN ACTIONSCRIPT 2 DAN XML. In M. Munandar, PEMETAAN INTERAKTIF LETAK TOKO LANTAI 1 DI PASAR ATJEH MENGGUNAKAN ACTIONSCRIPT 2 DAN $X M L$. Banda Aceh: Universitas Syiahkuala.

Rahman, A. (2019). Pengantar Kartografi \& Sistim Informasi Geografis (Teori dan Praktik). In A. Rahman, Pengantar Kartografi \& Sistim Informasi Geografis (Teori dan Praktik). Universitas Lambung Mangkurat Press. 